\title{
Improved synthesis of $4-\left[{ }^{18} \mathrm{~F}\right]$ fluoro-m- hydroxyphenethylguanidine using an iodonium ylide precursor
}

\author{
Yong-Woon Jung | Guie Gu | David M. Raffel
}

Division of Nuclear Medicine, Department of Radiology, University of Michigan Medical School, Ann Arbor, Michigan, USA

\section{Correspondence}

David M. Raffel, Division of Nuclear Medicine, Department of Radiology University of Michigan Medical School, 2276 Medical Science I, SPC-5610, Ann Arbor, MI 48109, USA. (734) 936-0725, FAX:(734) 764-0288.

Email: raffel@umich.edu
Fluorine-18 labeled hydroxyphenethylguanidines were recently developed in our laboratory as a new class of PET radiopharmaceuticals for quantifying regional cardiac sympathetic nerve density in heart disease patients. Studies of $4-\left[{ }^{18} \mathrm{~F}\right]$ fluoro- $m$-hydroxyphenethylguanidine $\left(\left[{ }^{18} \mathrm{~F}\right] 4 \mathrm{~F}-\mathrm{MHPG}\right)$ and $3-\left[{ }^{18} \mathrm{~F}\right]$ fluoro- $p$-hydroxyphenethylguanidine $\left(\left[{ }^{18} \mathrm{~F}\right] 3 \mathrm{~F}-\mathrm{PHPG}\right)$ in human subjects have shown that these radiotracers can be used to generate high-resolution maps of regional sympathetic nerve density using the Patlak graphical method. Previously, these compounds were synthesized using iodonium salt precursors, which provided sufficient radiochemical yields for on-site clinical PET studies. However, we were interested in exploring new methods that could offer significantly higher radiochemical yields. Spirocyclic iodonium ylide precursors have recently been established as an attractive new approach to radiofluorination of electron-rich aromatic compounds, offering several advantages over iodonium salt precursors. The goal of this study was to prepare a spirocyclic iodonium ylide precursor for synthesizing $\left[{ }^{18} \mathrm{~F}\right] 4 \mathrm{~F}-\mathrm{MHPG}$ and evaluate its efficacy in production of this radiopharmaceutical. Under optimized automated reaction conditions, the iodonium ylide precursor provided radiochemical yields averaging $7.8 \% \pm 1.4 \%$ ( $n=8$, EOS, not decay corrected), around threefold higher than those achieved previously using an iodonium salt precursor. With further optimization and scale-up, this approach could potentially support commercial distribution of $\left[{ }^{18} \mathrm{~F}\right] 4 \mathrm{~F}-\mathrm{MHPG}$ to $\mathrm{PET}$ centers without on-site radiochemistry facilities.

\section{KEYWORDS}

cardiac sympathetic innervation, hypervalent iodine, iodonium ylides, radiofluorination

\section{1 | INTRODUCTION}

Noninvasive assessment of the extent and severity of regional cardiac denervation using radiopharmaceuticals that selectively localize in sympathetic nerve terminals is an emerging approach to assessing the risk of sudden cardiac death in patients with heart failure. ${ }^{1}$ Our laboratory has recently developed ${ }^{18}$ F-labeled hydroxyphenethylguanidines as a new class of radiopharmaceuticals for quantifying regional cardiac sympathetic nerve density using PET and tracer kinetic analysis. Our studies have focused on $4-\left[{ }^{18} \mathrm{~F}\right]$ fluoro- $m$-hydroxyphenethylguanidine $\left(\left[{ }^{18} \mathrm{~F}\right] 4 \mathrm{~F}\right.$ MHPG) and its structural isomer $3-\left[{ }^{18} \mathrm{~F}\right]$ fluoro- $p$ hydroxyphenethylguanidine ([$\left.\left.{ }^{18} \mathrm{~F}\right] 3 \mathrm{~F}-\mathrm{PHPG}\right)$ (Figure 1). 
$\left[{ }^{18} \mathrm{~F}\right] 4 \mathrm{~F}-\mathrm{MHPG}$<smiles>N=C(N)NCCc1ccc(F)c(O)c1</smiles><smiles>N=C(N)NCCc1ccc(O)c(F)c1</smiles>

$\left[{ }^{18} \mathrm{~F}\right] 3 \mathrm{~F}-\mathrm{PHPG}$
FIGURE 1 The structures of $\left[{ }^{18} \mathrm{~F}\right] 4 \mathrm{~F}-\mathrm{MHPG}$ and $\left[{ }^{18} \mathrm{~F}\right] 3 \mathrm{~F}-\mathrm{PHPG}$

These radiotracers exhibit irreversible tissue kinetics through efficient intraneuronal retention in the norepinephrine storage vesicles localized in cardiac sympathetic nerve terminals. We previously described the use of iodonium salt precursors with the guanidine group completely protected (tetrakis-Boc) as an effective method for automated production of $\left[{ }^{18} \mathrm{~F}\right] 4 \mathrm{~F}-\mathrm{MHPG}$ and $\left[{ }^{18} \mathrm{~F}\right] 3 \mathrm{~F}-$ PHPG. ${ }^{2}$ For example, in production runs of $\left[{ }^{18} \mathrm{~F}\right] 4 \mathrm{~F}-\mathrm{MHPG}$ $(n=15)$, this approach provided final product yields averaging $1.56 \pm 0.68 \mathrm{GBq}$ (range 0.61-2.84 GBq) at end of synthesis (EOS) with molar activities averaging $58 \pm 25 \mathrm{GBq} /$ $\mu \mathrm{mol}$ (range 21-105 GBq/ $\mu \mathrm{mol}$ ), which were adequate for on-site clinical studies. Under an exploratory Investigational New Drug clearance from the US Food and Drug Administration, we recently conducted first-in-human studies of $\left[{ }^{18} \mathrm{~F}\right] 4 \mathrm{~F}-\mathrm{MHPG}$ and $\left[{ }^{18} \mathrm{~F}\right] 3 \mathrm{~F}-\mathrm{PHPG}$ in healthy control subjects. ${ }^{3}$ Encouraged by the positive results of these studies, we were interested in evaluating alternative approaches to the production of $\left[{ }^{18} \mathrm{~F}\right]$ fluoro-hydroxyphenethylguanidines with the goal of achieving higher radiochemical yields for routine clinical production. Among several new methods developed for radiofluorination of electron-rich arenes, spirocyclic iodonium ylides offer several advantages, including excellent regioselectivity, high radiochemical yields, and mild, metal-free reaction conditions. $^{4-7}$ In practice, the spirocyclic iodonium ylide approach is quite similar to our established method using iodonium salt precursors. The goal of this study was to prepare and evaluate the spirocyclic iodonium ylide analog of the iodonium salt precursor used previously for $\left[{ }^{18} \mathrm{~F}\right] 4 \mathrm{~F}$ MHPG production to test the general utility of iodonium ylide method for radiofluorination of ${ }^{18} \mathrm{~F}$-labeled hydroxyphenethylguanidines. The results demonstrate that this new approach significantly increases the achievable radiochemical yields of $\left[{ }^{18} \mathrm{~F}\right] 4 \mathrm{~F}-\mathrm{MHPG}$, providing yet another example of the effectiveness of the use of spirocyclic ylide precursors for efficient radiofluorination of electron-rich aromatic compounds.

\section{2 | RESULTS AND DISCUSSION}

The synthesis of the required tetrakis-Boc protected spirocyclic iodonium ylide precursor $\mathbf{2}$ is shown in Scheme 1. Compound $\mathbf{1}\left(N, N^{\prime}, N^{\prime \prime}, N^{\prime \prime}\right.$-tetrakis (tertbutoxycarbonyl)- $N$-3-benzyloxy-4-

iodophenethylguanidine), previously synthesized for our original approach to $\left[{ }^{18} \mathrm{~F}\right] 4 \mathrm{~F}-\mathrm{MHPG},{ }^{2}$ was first reacted with dimethyldioxirane (DMDO). The resulting intermediate was coupled with $(1 r, 3 r, 5 r, 7 r)$-spiro[adamantan$2,2^{\prime}$-[1,3]-dioxane]-4', $6^{\prime}$-dione (SPIAd) ${ }^{5}$ to give the spirocyclic iodonium ylide 2 .

For initial automated radiofluorination tests with $\mathbf{2}$, we employed optimized reaction conditions reported by Rotstein et $\mathrm{al},{ }^{5}$ including the use of tetraethylammonium bicarbonate (TEAB; $4.0 \mathrm{mg}$ ) as the fluorine- 18 counter ion, anhydrous $N, N$-dimethylformamide (DMF, $0.5 \mathrm{~mL}$ ) as the reaction solvent, 5.0 to $6.0 \mathrm{mg}$ of 2 , and reaction conditions of $120^{\circ} \mathrm{C}$ for 10 minutes (Scheme 2). The subsequent steps for simultaneous deprotection of the benzyl ether and the $N, N^{\prime}, N^{\prime \prime}, N^{\prime \prime}$-tetrakis-Boc groups using $3.0 \mathrm{~N}$ $\mathrm{HBr}$ followed by HPLC purification of $\left[{ }^{18} \mathrm{~F}\right] 4 \mathrm{~F}-\mathrm{MHPG}$ were identical to those used in our original method. ${ }^{2}$ Radiochemical yields of these pilot tests (Table 1, Runs 1-3) were dramatically higher than our original approach,

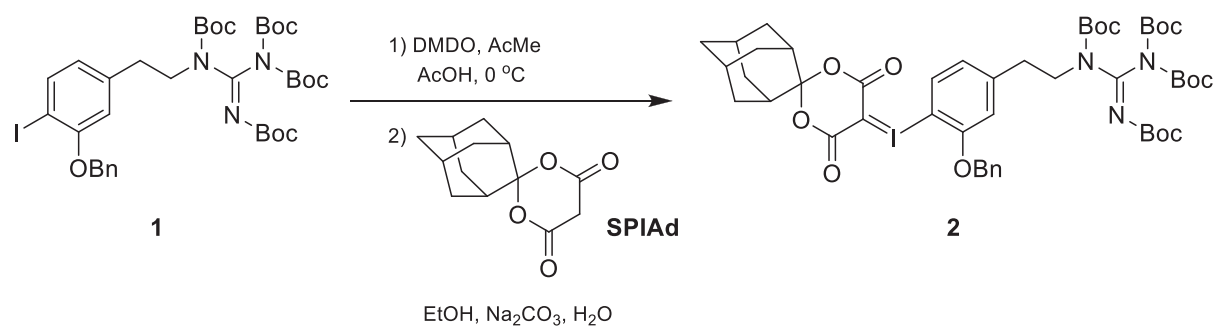

SCHEME 1 The synthesis of the spirocyclic iodonium ylide precursor 2

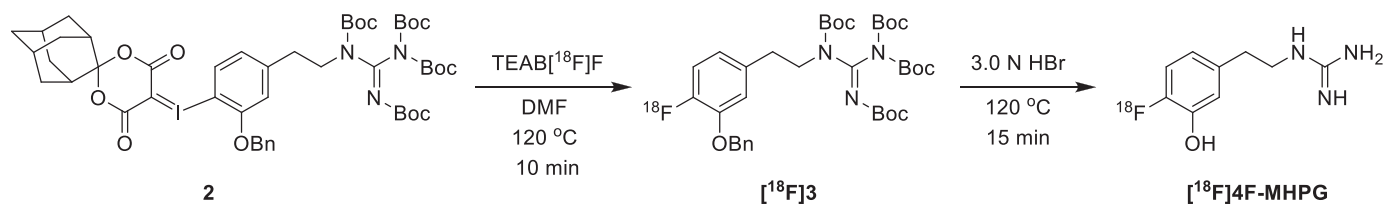

SCHEME 2 The two-step reaction yielding $\left[{ }^{18} \mathrm{~F}\right] 4 \mathrm{~F}-\mathrm{MHPG}$ from precursor 2 
TABLE 1 Automated tests of $\left[{ }^{18} \mathrm{~F}\right]$ FF-MHPG production with spirocyclic iodonium ylide precursor 2

\begin{tabular}{|c|c|c|c|c|c|c|c|}
\hline Run \# & $\mathrm{X}^{+}\left[{ }^{18} \mathrm{~F}\right] \mathrm{F}^{-}$ & Solvent & $\begin{array}{l}\text { Temperature, } \\
{ }^{\circ} \mathrm{C}\end{array}$ & $\begin{array}{l}\text { Reaction } \\
\text { Time, min }\end{array}$ & $\begin{array}{l}\text { Radiochemical } \\
\text { Purity, \% }\end{array}$ & $\begin{array}{l}\text { Radiochemical } \\
\text { Yield, \% }\end{array}$ & $\begin{array}{l}\text { Molar } \\
\text { Activity, } \\
\text { GBq/ } / \text { mol }\end{array}$ \\
\hline 1 & $\mathrm{TEA}^{+}$ & DMF & 120 & 10 & $>98$ & 8.4 & - \\
\hline 2 & $\mathrm{TEA}^{+}$ & DMF & 120 & 10 & $>98$ & 9.4 & - \\
\hline 3 & $\mathrm{TEA}^{+}$ & DMF & 120 & 10 & $>99$ & 9.7 & - \\
\hline 4 & $\mathrm{Cs}^{+}$ & DMF & 120 & 10 & - & - & - \\
\hline 5 & $\mathrm{~K}^{+} / \mathrm{K} 222$ & DMF & 120 & 10 & $>89$ & 0.3 & - \\
\hline 6 & $\mathrm{~K}^{+} / \mathrm{K} 222$ & DMF & 120 & 10 & $>96$ & 1.1 & - \\
\hline 7 & $\mathrm{TEA}^{+}$ & $\mathrm{MeCN}$ & 120 & 10 & $>75$ & 0.4 & - \\
\hline 8 & $\mathrm{TEA}^{+}$ & $\mathrm{MeCN}$ & 120 & 10 & $>95$ & 1.0 & - \\
\hline 9 & $\mathrm{TEA}^{+}$ & DMF & 150 & 3 & $>99$ & 3.8 & - \\
\hline 10 & $\mathrm{TEA}^{+}$ & DMF & 120 & 5 & $>96$ & 6.2 & - \\
\hline 11 & $\mathrm{TEA}^{+}$ & DMF & 120 & 10 & $>98$ & 8.3 & - \\
\hline $\mathrm{QC1}$ & $\mathrm{TEA}^{+}$ & DMF & 120 & 10 & $>99$ & 6.9 & 130.5 \\
\hline QC2 & $\mathrm{TEA}^{+}$ & DMF & 120 & 10 & $>99$ & 5.8 & 105.8 \\
\hline QC3 & $\mathrm{TEA}^{+}$ & DMF & 120 & 10 & $>99$ & 6.7 & 137.9 \\
\hline QC4 & $\mathrm{TEA}^{+}$ & DMF & 120 & 10 & $>99$ & 7.0 & $>225$ \\
\hline
\end{tabular}

Note. Reactions were performed in $0.5 \mathrm{~mL}$ of solvent using 5.0 to 6.6 - $\mathrm{mg}$ precursor and 3.5 to $5.4 \mathrm{mg}$ of fluoride counter ion. Symbol “-“denotes that the value was not determined. K222 = Kryptofix 222.

averaging $9.2 \% \pm 0.7 \%$ (range $8.4 \%-9.7 \%$ ) at EOS (not decay corrected), more than threefold higher than the average yield of $\left[{ }^{18} \mathrm{~F}\right] 4 \mathrm{~F}-\mathrm{MHPG}$ achieved with our iodonium salt precursor approach. ${ }^{2}$

Encouraged by these trial studies, we sought to optimize reaction conditions through a series of manual reaction tests. First, we tested the effect of using different fluorine-18 counter ions, including $\mathrm{TEA}^{+}, \mathrm{K}^{+} /$Kryptofix 222, and $\mathrm{Cs}^{+}$. The results showed that $\mathrm{TEA}^{+}$was the clear choice, as $\mathrm{K}^{+} /$Kryptofix 222 and $\mathrm{Cs}^{+}$yielded only trace quantities of radiolabeled intermediate (data not shown). Next, we tested acetonitrile as the reaction solvent, based on a report suggesting it might provide better yields, ${ }^{8}$ but again, low yields of product were obtained (data not shown). Finally, reaction temperatures and times were optimized using $\mathrm{TEA}^{+}$as the fluoride counter ion and DMF as the solvent. The effects of reaction temperature and reaction time using $4 \mathrm{mg}$ of TEAB in $0.5 \mathrm{~mL}$ of DMF solvent are shown in Figure 2A. The best yields were obtained at $120^{\circ} \mathrm{C}$ for reaction times between 3 and 10 minutes. Tests of three different concentrations of the fluoride counter ion showed that $4 \mathrm{mg}$ of TEAB per $0.5 \mathrm{~mL}$ of DMF solvent gave the highest yields at a reaction temperature of $120^{\circ} \mathrm{C}$ and reaction times of 5 to 10 minutes (Figure 2B). The general trend of decreasing radiochemical yields with longer-reaction times is likely due to a combination of thermal decomposition of the spirocyclic iodonium ylide $\mathbf{2}$ and the radiolabeled intermediate $\left[{ }^{18} \mathrm{~F}\right] 3$. For example, melting point tests of 2 showed a broad melting point around $80^{\circ} \mathrm{C}$ to $89^{\circ} \mathrm{C}$, followed by generation of bubbles in the open capillary tube at temperatures between $110^{\circ} \mathrm{C}$ and $120^{\circ} \mathrm{C}$. We hypothesize that the bubbles were caused by generation of $\mathrm{CO}_{2}$ during thermolysis of the $N, N^{\prime}, N^{\prime \prime}, N^{\prime \prime}$-tetrakisBoc groups between $110^{\circ} \mathrm{C}$ and $120^{\circ} \mathrm{C} .^{9,10}$

The findings of the initial automated tests (Table 1, Runs 1-3) and the manual reaction tests were confirmed in some additional automated production runs of $\left[{ }^{18} \mathrm{~F}\right] 4 \mathrm{~F}-\mathrm{MHPG}$. Automated syntheses using $\mathrm{Cs}^{+}$and $\mathrm{K}$ +/Kryptofix 222 as fluoride counter ions in DMF solvent were again found to provide extremely low yields (Table 1, Runs 4-6). Similarly, yields were very low using $\mathrm{TEA}^{+}$as the fluoride counter ion in $\mathrm{MeCN}$ solvent (Table 1, Runs 7-8). Using $\mathrm{TEA}^{+}$in DMF, a short reaction time of 3 minutes at high temperature $\left(150^{\circ} \mathrm{C}\right.$ ) gave a moderate yield of $3.8 \%$ (Table 1, Run 9), while a higher yield of $6.2 \%$ was achieved for a 5minute reaction time at $120^{\circ} \mathrm{C}$ (Table 1, Run 10). Finally, a few runs were performed using optimized conditions $\left(\mathrm{TEA}^{+}\right.$in $\mathrm{DMF}$ for $10 \mathrm{~min}$ at $120^{\circ} \mathrm{C}$ ), and the final products were analyzed with the series of quality control (QC) tests currently used at our institution for clinical PET studies with this radiopharmaceutical (Table 1, Runs QC1-QC4). The time from end-of-beam to formulation was 90 to 95 minutes, including HPLC purification. An example of the HPLC data acquired 

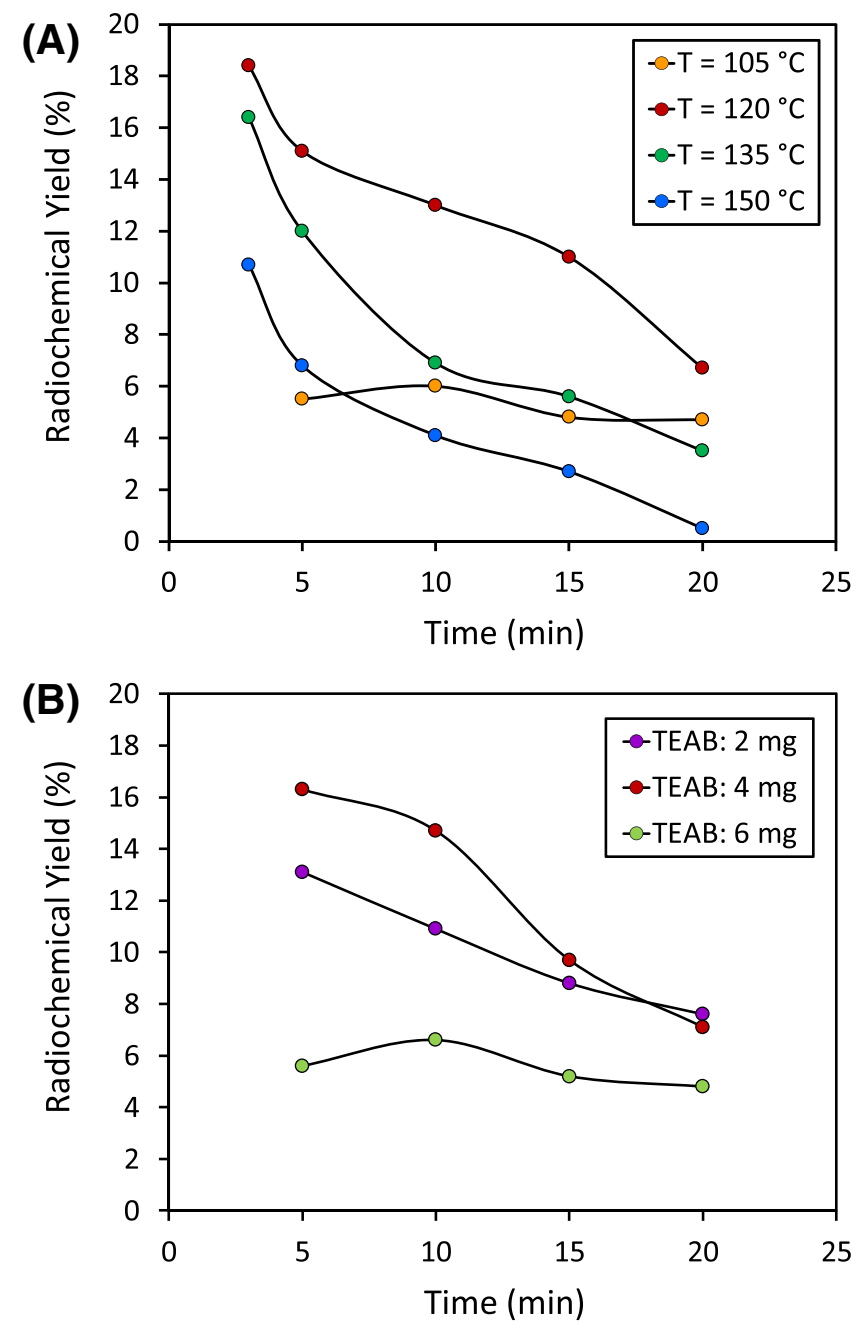

FIGURE 2 Radiochemical yields of the radiolabeled intermediate $\left[{ }^{18} \mathrm{~F}\right] \mathbf{3}$ as a function of reaction time for $(\mathrm{A})$ different reaction temperatures and (B) different amounts of tetraethylammonium bicarbonate (TEAB)

during purification and collection of $\left[{ }^{18} \mathrm{~F}\right] 4 \mathrm{~F}-\mathrm{MHPG}$ is shown in Figure 3. Good radiochemical yields were achieved (5.8\%-8.3\%), consistent with the findings of the manual reaction tests. Radiochemical purities were high (>99\%), and molar activities ranged from 105.8 to greater than $225 \mathrm{GBq} / \mathrm{mmol}$ (Table 1). All other QC tests (mass concentration, radiochemical identity, radionuclidic identity, $\mathrm{pH}$, visual inspection for particulates and color, residual solvents tests, ethanol content, filter membrane integrity, and sterility) were passed by each batch of $\left[{ }^{18} \mathrm{~F}\right] 4 \mathrm{~F}-\mathrm{MHPG}$. Representative data of an HPLC study to confirm radiochemical identity of the product are shown in Figure 4. Together, these results demonstrate the ability of the spirocyclic iodonium ylide method to reliably produce $\left[{ }^{18} \mathrm{~F}\right] 4 \mathrm{~F}$ MHPG for clinical PET studies.

While the United States Pharmacopeia (USP) does not cite a release limit for tetraethylammonium ion $\left(\mathrm{TEA}^{+}\right)$,
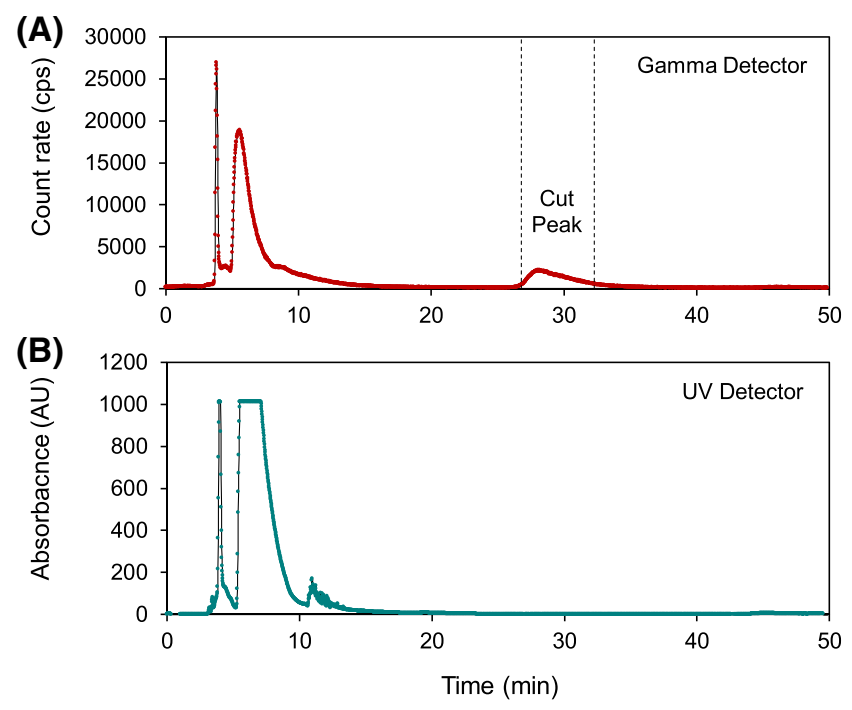

FIGURE 3 HPLC purification of $\left[{ }^{18} \mathrm{~F}\right] 4 \mathrm{~F}-\mathrm{MHPG}$; (A) radiation detector chromatogram, showing collection of $\left[{ }^{18} \mathrm{~F}\right] 4 \mathrm{~F}-\mathrm{MHPG}$ from 27 to 32 minutes and (B) the corresponding UV detector data at $\lambda=220 \mathrm{~nm}$

Institutional Review Boards may require QC testing of $\mathrm{TEA}^{+}$concentrations in the final $\left[{ }^{18} \mathrm{~F}\right] 4 \mathrm{~F}-\mathrm{MHPG}$ formulation. For example, the European Pharmacopeia sets a release limit for the closely related tetrabutylammonium ion $\left(\mathrm{TBA}^{+}\right.$) of $2.6 \mathrm{mg} / \mathrm{V}$ (per patient dose), and QC tests have been developed to evaluate $\mathrm{TBA}^{+}$levels in PET radiopharmaceutical products. ${ }^{11}$ Since our optimized iodonium ylide approach to $\left[{ }^{18} \mathrm{~F}\right] 4 \mathrm{~F}-\mathrm{MHPG}$ uses $4.0 \mathrm{mg}$ of $\mathrm{TEA}^{+}$, and the compound is purified using HPLC, it is unlikely that residual $\mathrm{TEA}^{+}$levels would preclude use of the final product in human subjects. Supporting this, a recent report on an improved synthesis of $\left[{ }^{18} \mathrm{~F}\right]$ fluorodopamine for human studies (which uses HPLC purification of the final product) described a QC testing method for $\mathrm{TEA}^{+}$concentrations, which averaged around $50 \mu \mathrm{g} / \mathrm{mL}$ when starting with up to $3.5 \mathrm{mg}$ of tetraethylammonium bicarbonate per reaction. ${ }^{12}$

The radiochemical yields of $\left[{ }^{18} \mathrm{~F}\right] 4 \mathrm{~F}-\mathrm{MHPG}$ achieved with the spirocyclic iodonium ylide 2 under optimized reaction conditions averaged $7.8 \% \pm 1.4 \%(n=8$, range 5.8\%-9.7\%, Table 1). In comparison, these are lower than the reported yield of $14 \%$ achieved with a closely related spirocyclic iodonium ylide precursor to prepare meta- $\left[{ }^{18} \mathrm{~F}\right]$ fluoro-benzylguanidine $\left(\left[{ }^{18} \mathrm{~F}\right] \mathrm{mFBG}\right){ }^{5}$ This is not surprising, as the protected $m$-hydroxyl group in precursor 2 is electron-rich, which would be expected to cause lower radiochemical yields for our compound. Nevertheless, the higher and more consistent radiochemical yields of $\left[{ }^{18} \mathrm{~F}\right] 4 \mathrm{~F}-\mathrm{MHPG}$ achieved using 2 compared with our earlier results using an iodonium salt precursor represents a noteworthy improvement in the production of this radiopharmaceutical for clinical use. 

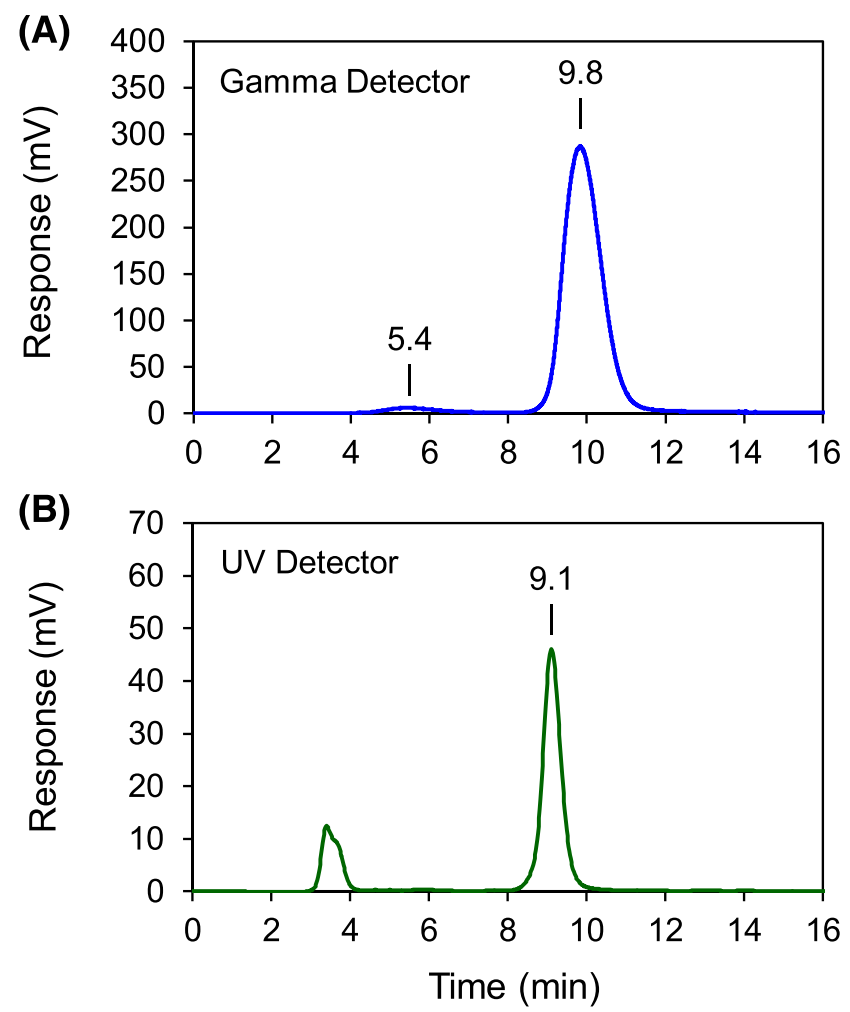

FIGURE 4 Coinjection study to confirm radiochemical identity. An aliquot of $\left[{ }^{18} \mathrm{~F}\right] 4 \mathrm{~F}-\mathrm{MHPG}$ product was spiked with cold standard $\left[{ }^{19} \mathrm{~F}\right] 4 \mathrm{~F}-\mathrm{MHPG}$ and analyzed using HPLC. The relative retention times of the peaks in the UV chromatogram $\left(R_{\mathrm{t}}=9.1 \mathrm{~min}\right)$ and the radiation detector chromatogram $\left(R_{\mathrm{t}}=9.8 \mathrm{~min}\right)$ is consistent with an established delay time of 0.7 minutes between the UV and radiation detectors. A small amount of free $\left[{ }^{18} \mathrm{~F}\right] \mathrm{F}^{-}(\sim 2 \%$ of the total activity) appears at $R_{\mathrm{t}}=5.4$ minutes in the radiation detector trace. HPLC conditions: Synergi $10 \mu$ Hydro-RP column, $4.6 \times 250 \mathrm{~mm}, 60 \mathrm{mM}$ sodium phosphate buffer, $\mathrm{pH} 5.4$ with $10 \%$ ethanol, flow rate $1.0 \mathrm{~mL} / \mathrm{min}$, UV absorbance at $220 \mathrm{~nm}$

\section{3 | CONCLUSIONS}

The use of a spirocyclic iodonium ylide precursor for automated production of the cardiac sympathetic innervation radiotracer $\left[{ }^{18} \mathrm{~F}\right] 4 \mathrm{~F}-\mathrm{MHPG}$ was evaluated and found to consistently provide higher radiochemical yields than the previous approach using an iodonium salt precursor. This improved method of $\left[{ }^{18} \mathrm{~F}\right] 4 \mathrm{~F}-\mathrm{MHPG}$ production is well suited to on-site production for clinical PET studies and could possibly be scaled up for distribution of the radiotracer to stand-alone PET centers without a cyclotron and radiochemistry facility.

\section{4 | EXPERIMENTAL}

\section{1 | General}

Reagents and solvents were purchased from commercial sources and used without further purification unless otherwise noted. $N, N^{\prime}, N^{\prime \prime}, N^{\prime \prime}$-tetrakis (tert-butoxycarbonyl)- $N$-3-benzyloxy-4-iodophenethylguanidine $\mathbf{1}, N, N^{\prime}$, $N^{\prime \prime}, N$ "-tetrakis (tert-butoxycarbonyl)- $N$-3-benzyloxy-4-fluo -rophenethylguanidine 3, and 4-fluoro- $m$-hydroxyphenethylguanidine (4F-MHPG) were previously prepared in our laboratory. ${ }^{2,13,14}$ Compound $\mathbf{1}$ was used to synthesize the spirocyclic iodonium ylide precursor $\mathbf{2}$. Compound $\mathbf{3}$ and 4F-MHPG were used as reference standards for radio-HPLC and radio-TLC analysis. $\mathrm{DMDO}^{15}$ and $(1 r$, $3 r, 5 r, 7 r$ )-spiro[adamantan-2,2'-[1,3]-dioxane]-4',6'-dione $(\text { SPIAd })^{5}$ were prepared using previously reported methods.

NMR spectra were obtained on a Varian vnmrs 500 (500.10 MHz for ${ }^{1} \mathrm{H}$; $125.70 \mathrm{MHz}$ for ${ }^{13} \mathrm{C}$ ) spectrometer. ${ }^{1} \mathrm{H}$ and ${ }^{13} \mathrm{C}$ NMR chemical shifts $(\delta)$ are reported in parts per million (ppm) relative to internal standard TMS, and coupling constants $(J)$ are in Hz. High-resolution mass spectra were obtained on a VG (Micromass) 70-250S spectrometer using electrospray ionization (ESI) in positive ion mode at $70 \mathrm{eV}$. Flash column chromatography was performed with E. Merck 230-400 mesh silica gel.

\section{2 | Precursor synthesis}

\subsection{1 | $(1 r, 3 r, 5 r, 7 r)$-spiro[adamantane-2,2' - [1,3]dioxane]-4' $\mathbf{6}^{\prime}$-dion-[2-benzyloxy-4-\{2' - $\left(N, N^{\prime}, N^{\prime \prime}, N^{\prime \prime}\right.$-tetrakis (tert-butoxycarbonyl)- guanidinyl)ethyl\}phenyliodonium] ylide (2)}

A solution of DMDO in acetone was added dropwise to a cooled $\left(0^{\circ} \mathrm{C}\right)$ solution of $N, N^{\prime}, N^{\prime \prime}, N^{\prime \prime}$-tetrakis (tertbutoxycarbonyl)- $N$-3-benzyloxy-4-

iodophenethylguanidine $\mathbf{1}(200 \mathrm{mg}, 0.25 \mathrm{mmol})$ in acetone and acetic acid $(4: 1,2.5 \mathrm{~mL})$ until the starting guanidine compound $\mathbf{1}$ had disappeared, as assessed by TLC analysis. The mixture was stirred at $0^{\circ} \mathrm{C}$ for 1 hour and then warmed to room temperature. It was then concentrated under reduced pressure. The residue was diluted with ethanol $(5 \mathrm{~mL})$ and treated by addition of $(1 r, 3 r, 5 r, 7 r)$-spiro[adamantan-2,2'-[1,3]-dioxane]-4', $6^{\prime}$ -

dione (SPIAd, $70 \mathrm{mg}$ ) in portions. The resulting solution was adjusted to $\mathrm{pH} 10$ by addition of a $10 \%$ aqueous $\mathrm{Na}_{2} \mathrm{CO}_{3}$ solution, stirred for 2 hours at room temperature, diluted with water $(10 \mathrm{~mL})$, and then extracted with ethyl acetate $(3 \times 50 \mathrm{~mL})$. The combined extracts were washed with brine, dried over anhydrous $\mathrm{Na}_{2} \mathrm{SO}_{4}$, and concentrated under reduced pressure. The residue was purified by flash column chromatography (silica gel, 30\%-40\% ethyl acetate in hexane) to afford the product 2 (179 $\mathrm{mg}$, $69 \%)$ as a white solid; ${ }^{1} \mathrm{H}$ NMR $\left(500 \mathrm{MHz}, \mathrm{CDCl}_{3}\right) \delta$ 7.44-7.39 (m, 5H), 7.25 (d, $J=7.9 \mathrm{~Hz}, 1 \mathrm{H}), 7.04(\mathrm{~s}, 1 \mathrm{H})$, $6.99(\mathrm{~d}, J=7.9 \mathrm{~Hz}, 1 \mathrm{H}), 5.21(\mathrm{~s}, 2 \mathrm{H}), 3.94(\mathrm{t}, J=8.0 \mathrm{~Hz}$, 
2H), 2.98 (t, $J=8.0 \mathrm{~Hz}, 2 \mathrm{H}$ ), 2.52 (br. s, 2H), 2.22 (br. s, 2H), 2.20 (br. s, 2H), 1.88 (br. s, 2H), 1.74 (br. s, 4H), 1.72 (br. s, $2 \mathrm{H}), 1.52-1.47(\mathrm{~m}, 36 \mathrm{H}) ;{ }^{13} \mathrm{C} \mathrm{NMR}(125 \mathrm{MHz}$, $\left.\mathrm{CDCl}_{3}\right) \delta 163.80,157.98,154.82,151.38,147.80,145.06$, $144.12,135.10,129.26,129.21,129.14,128.32,125.59$, $114.86,107.90,100.19,84.32,84.17,82.53,72.44,48.79$, $37.53,36.95,35.96,34.08,33.46,28.34,28.27,28.25$, 26.88; HRMS $\left(\mathrm{ESI}^{+}\right) \mathrm{m} / z$ calculated for $\mathrm{C}_{49} \mathrm{H}_{64} \mathrm{IN}_{3} \mathrm{O}_{13}$ $[\mathrm{M}+\mathrm{Na}]^{+}:$1052.3376, found 1052.3373.

\section{3 | Radiochemistry}

\subsection{1 | General}

Ethanol (200 proof, USP) was purchased from Decon Laboratories, Inc. USP grade sodium chloride $0.9 \%$, and sterile water for injection, were sourced from Hospira. Millex GV (\#SLGV013SL) and FG (\#SLFG025LS) filters were purchased from Millipore. Sep-Pak Light QMA cartridges (\#WAT023525) were purchased from Waters Corporation. Light QMA cartridges were conditioned with sequential flushes of $10 \mathrm{~mL}$ of ethanol, followed by $10 \mathrm{~mL}$ of sterile water, $10 \mathrm{~mL}$ of $0.5 \mathrm{M} \mathrm{NaHCO}_{3}$ preconditioning solution, and finally $10 \mathrm{~mL}$ of sterile water prior to use.

Using a GE Healthcare PETrace 880 cyclotron, a target containing water enriched with ${ }^{18} \mathrm{O}$ was irradiated with $16 \mathrm{MeV}$ protons to yield $\left[{ }^{18} \mathrm{~F}\right]$ fluoride $\left(\left[{ }^{18} \mathrm{~F}\right] \mathrm{F}^{-}\right)$via the ${ }^{18} \mathrm{O}(p, n){ }^{18} \mathrm{~F}$ reaction. $\left[{ }^{18} \mathrm{~F}\right] \mathrm{F}^{-}$was isolated from the enriched water by trapping on a preconditioned Sep-Pak Light QMA cartridge. The $\left[{ }^{18} \mathrm{~F}\right]$ fluoride was then used in manual reaction tests or for automated radiosyntheses of $\left[{ }^{18} \mathrm{~F}\right] 4 \mathrm{~F}-\mathrm{MHPG}$ using a TRACERLab $\mathrm{FX}_{\mathrm{FN}}$ synthesis module. Radiochemical reactions were analyzed by radio-TLC or HPLC. For manual tests, radio-TLC analysis was performed using a Bioscan AR 2000 Radio-TLC scanner with EMD Millipore TLC silica gel 60 plates $(3.0 \times 6.5$ $\mathrm{cm})$. For the automated syntheses, the radiochemical purity of $\left[{ }^{18} \mathrm{~F}\right] 4 \mathrm{~F}-\mathrm{MHPG}$ was measured using a Shimadzu LC-2010A HT system equipped with a Bioscan B-FC-1000 radiation detector under isocratic conditions (Jupiter $\mathrm{C} 18$ $5 \mu$ column, $4.6 \times 250 \mathrm{~mm}, 60 \mathrm{mM} \mathrm{NaHPO}{ }_{4}$ buffer, $\mathrm{pH}$ 5.4, with $10 \%$ ethanol, flow rate $1.1 \mathrm{~mL} / \mathrm{min}, \lambda=254$ $\mathrm{nm}, 40^{\circ} \mathrm{C}$ oven). A few batches of $\left[{ }^{18} \mathrm{~F}\right] 4 \mathrm{~F}-\mathrm{MHPG}$ prepared under optimized automated reaction conditions were tested using the full QC protocol developed for human PET studies, including molar activity determination and residual solvents analyses.

\subsection{2 | Manual reactions}

Tetraethylammonium $\left[{ }^{18} \mathrm{~F}\right]$ fluoride $\left(\mathrm{Et}_{4} \mathrm{~N}\left[{ }^{18} \mathrm{~F}\right] \mathrm{F}\right)$ was prepared using a TRACERLab FX $_{\mathrm{FN}}$ synthesis module
(General Electric, GE). $\left[{ }^{18} \mathrm{~F}\right] \mathrm{F}^{-}$was produced using a short beam time on the GE PETrace cyclotron (55 $\mu \mathrm{A}$ beam for 30-45 s) and trapped on a preconditioned SepPak Light QMA cartridge. The trapped $\left[{ }^{18} \mathrm{~F}\right] \mathrm{F}^{-}$was eluted into the reaction vessel with a mixture of tetraethylammonium bicarbonate $\left(\mathrm{Et}_{4} \mathrm{NHCO}_{3}, 4.0 \mathrm{mg}\right)$, $\mathrm{H}_{2} \mathrm{O}(0.3 \mathrm{~mL})$, and $\mathrm{MeCN}(0.7 \mathrm{~mL})$. After additional $\mathrm{MeCN}(0.5 \mathrm{~mL})$ was added to the reaction vessel, the resulting solution was azeotropically dried under vacuum at $90^{\circ} \mathrm{C}$ for 4 minutes, followed by a nitrogen stream and simultaneous vacuum draw at $70^{\circ} \mathrm{C}$ for an additional 4 minutes. Anhydrous N,N-dimethylformamide (6 mL) was added into the reaction vessel, and the resulting solution was transferred to a sterile vial to provide approximately $1.5 \mathrm{GBq}$ of anhydrous $\mathrm{Et}_{4} \mathrm{~N}\left[{ }^{18} \mathrm{~F}\right] \mathrm{F}$ for manual radiolabeling tests.

Manual reaction tests for optimizing radiolabeling conditions using the spirocyclic iodonium ylide precursor 2 were carried out using different reaction temperatures, reaction times, and tetraethylammonium bicarbonate concentrations. For most tests, a stock solution of $\mathrm{Et}_{4} \mathrm{NHCO}_{3}$ was prepared $\left(72.0 \mathrm{mg}\right.$ of dried $\mathrm{Et}_{4} \mathrm{NHCO}_{3}$ in $9.0 \mathrm{~mL}$ of anhydrous DMF, $41.8 \mathrm{mM}$ ), and aliquots of this solution were used for manual reactions. A $0.5-\mathrm{mL}$ aliquot of the $\mathrm{Et}_{4} \mathrm{NHCO}_{3}$ stock solution was added to a 4-mL amber glass vial containing precursor $2(\sim 4.0 \mathrm{mg}$, $3.8 \mu \mathrm{mol})$. The reaction vial was sealed with a PTFE/Silicone septum cap and the solution thoroughly mixed. Using a $100-\mu \mathrm{L}$ glass syringe, a $50-\mu \mathrm{L}$ aliquot of $\mathrm{Et}_{4} \mathrm{~N}\left[{ }^{18} \mathrm{~F}\right] \mathrm{F}$ (7.5-15.0 MBq, prepared as described above) was added to the reaction vial. The vial was then heated in an aluminum block at one of four temperatures (105, 120,135 , or $150^{\circ} \mathrm{C}$ ). After reaction times of $3,5,10,15$, or 20 minutes, a $10-\mu \mathrm{L}$ aliquot of the reaction mixture was withdrawn from the reaction vial and analyzed by radio-TLC (EtOAc/hexane, 1:3, v/v) to determine the radiochemical yield (\%) of the radiofluorinated intermediate $\left[{ }^{18} \mathrm{~F}\right] 3$ (see Scheme 2). Another series of tests evaluated the effect of different amounts of tetraethylammonium bicarbonate on radiochemical yields. Using a constant temperature of $120^{\circ} \mathrm{C}$, the radiochemical yields of $\left[{ }^{18} \mathrm{~F}\right] 3$ achieved with $2.0,4.0$, and 6.0 $\mathrm{mg}$ of $\mathrm{Et}_{4} \mathrm{NHCO}_{3}$ dissolved in the $0.5 \mathrm{~mL}$ of DMF added to the reaction vial were measured at reaction times of $5,10,15$, and 20 minutes.

\subsection{3 | Automated synthesis}

Our manual and automated reaction tests with the spirocyclic iodonium ylide precursor led to the following improved automated synthesis of $\left[{ }^{18} \mathrm{~F}\right] 4 \mathrm{~F}$ MHPG (Scheme 2). For a 30-minute target irradiation 
at $55-\mu \mathrm{A}$ beam current, approximately $65 \mathrm{GBq}$ of $\left[{ }^{18} \mathrm{~F}\right] \mathrm{F}$

- was produced and trapped on the preconditioned SepPak Light QMA cartridge. $\left[{ }^{18} \mathrm{~F}\right] \mathrm{F}^{-}$was eluted from the cartridge into the reactor vessel of the TRACERlab $\mathrm{FX}_{\mathrm{FN}}$ system with a solution of $\mathrm{Et}_{4} \mathrm{NHCO}_{3}(\sim 4 \mathrm{mg}$ in $0.4 \mathrm{~mL}$ of $\mathrm{H}_{2} \mathrm{O}$ and $1.0 \mathrm{~mL}$ of $\left.\mathrm{MeCN}\right)$. The water/acetonitrile mixture was evaporated under vacuum at $90^{\circ} \mathrm{C}$ for 4 minutes, followed by a nitrogen stream and simultaneous vacuum draw at $70^{\circ} \mathrm{C}$ for an additional 4 minutes to yield dried $\mathrm{Et}_{4} \mathrm{~N}\left[{ }^{18} \mathrm{~F}\right] \mathrm{F}$. After cooling to $60^{\circ} \mathrm{C}$, a mixed solution of $0.5 \mathrm{~mL}$ of $\mathrm{DMF}$ containing 5.5 to $6.0 \mathrm{mg}$ of the spirocyclic iodonium ylide precursor 2 was added to the reactor vessel containing $\mathrm{Et}_{4} \mathrm{~N}\left[{ }^{18} \mathrm{~F}\right] \mathrm{F}$. The mixture was heated in the sealed reactor vessel at $120^{\circ} \mathrm{C}$ for 10 minutes to produce 3-benzyloxy-4- $\left[{ }^{18} \mathrm{~F}\right]$ fluorophenethyl- $N, N^{\prime}, N^{\prime \prime}, N^{\prime \prime}$-tetrakisBOC-guanidine $\left[{ }^{18} \mathbf{F}\right] \mathbf{3}$ as intermediate. After cooling to $70^{\circ} \mathrm{C}$, a solution of $48 \% \mathrm{HBr}(0.5 \mathrm{~mL})$ and $\mathrm{MeCN}(0.5$ $\mathrm{mL}$ ) was added to the reaction mixture. The solution was heated at $120^{\circ} \mathrm{C}$ for 15 minutes and then cooled to $50^{\circ} \mathrm{C}$. Next, a mixture of aqueous $\mathrm{NaOH}(1.0 \mathrm{~mL}$, 4.0 $\mathrm{M}$ in $\mathrm{H}_{2} \mathrm{O}$ ) and buffer solution $(1.5 \mathrm{~mL}, 5 \% \mathrm{EtOH}$ in $40 \mathrm{mM} \mathrm{NH} \mathrm{NH}_{4} \mathrm{OAc}$ ) was added into the reactor vessel. This mixture was injected onto a reverse phase HPLC column (Phenomenex Synergi $10 \mu \mathrm{m}$ Hydro-RP $80 \AA$, $250 \times 10 \mathrm{~mm}, 5 \% \mathrm{EtOH}$ in $40 \mathrm{mM} \mathrm{NH}_{4} \mathrm{OAc}$ buffer, flow rate $4.0 \mathrm{~mL} / \mathrm{min}, \lambda=220 \mathrm{~nm}$ ), and $\left[{ }^{18} \mathrm{~F}\right] 4 \mathrm{~F}-\mathrm{MHPG}$ was collected at $R_{\mathrm{t}}=27$ to 32 minutes. The collected fraction was passed through a $0.22-\mu \mathrm{m}$ sterilizing filter directly into a septum-sealed, sterile, pyrogen-free glass vial. An aliquot of the filtered product was analyzed with HPLC to confirm the radiochemical identity as $\left[{ }^{18} \mathrm{~F}\right] 4 \mathrm{~F}-\mathrm{MHPG}$.

\subsection{4 | QC testing}

Molar activity was determined by analyzing an aliquot of $\left[{ }^{18} \mathrm{~F}\right] 4 \mathrm{~F}-\mathrm{MHPG}$ with known activity $A_{0}(\mathrm{kBq})$ using a reverse-phase HPLC system with radiodetection. The area under the UV absorbance peak associated with the $\left[{ }^{18} \mathrm{~F}\right] 4 \mathrm{~F}-\mathrm{MHPG}$ radioactivity peak was compared with a calibration curve to estimate the total mass of 4F-MHPG $(\mu \mathrm{g})$ in the aliquot. The ratio of sample activity $\left(A_{0}\right)$ to the measured total mass (converted from $\mu \mathrm{g}$ to $\mu \mathrm{mol}$ ) gave the molar activity of the sample. Radiochemical purity of the product was measured as the fractional area under $\left[{ }^{18} \mathrm{~F}\right] 4 \mathrm{~F}-\mathrm{MHPG}$ peak in the baseline-subtracted curve measured by the radiodetector. Additional QC tests included radiochemical identity, radionuclidic identity, radionuclidic purity, $\mathrm{pH}$, visual inspection for particulates and color, bacterial endotoxin test, and residual solvents testing.

\section{ACKNOWLEDGEMENTS}

We thank Dr Allen Brooks for helpful discussions about the TracerLab $\mathrm{FX}_{\mathrm{FN}}$ system and Bradford Henderson in the University of Michigan PET Radiopharmaceutical Production Program for performing quality control testing of several lots of $\left[{ }^{18} \mathrm{~F}\right] 4 \mathrm{~F}-\mathrm{MHPG}$.

\section{CONFLICT OF INTEREST}

The authors have no conflicts of interest to disclose.

\section{ORCID}

David M. Raffel (iD https://orcid.org/0000-0002-7188-9463

\section{REFERENCES}

1. Bengel FM, Thackeray JT. Altered cardiac innervation predisposes to ventricular arrhythmia: Targeted positron emission tomography identifies risk in ischemic cardiomyopathy. $J \mathrm{Am}$ Coll Cardiol. 2014;63(2):150-152.

2. Jung YW, Jang $\mathrm{KS}, \quad \mathrm{Gu} \quad \mathrm{G}$, et al. $\left[{ }^{18} \mathrm{~F}\right]$ Fluorohydroxyphenethylguanidines: efficient synthesis and comparison of two structural isomers as radiotracers of cardiac sympathetic innervation. ACS Chem Nerosci. 2017;8(7):1530-1542.

3. Raffel DM, Jung YW, Koeppe RA, et al. First-in-human studies of $\left[{ }^{18} \mathrm{~F}\right]$ fluorohydroxyphenethylguanidines: positron emission tomography radiotracers for quantifying regional cardiac sympathetic nerve density. Circ Cardiovasc Imaging. 2018;11:e007965.

4. Rotstein BH, Stephenson NA, Vasdev N, Liang SH. Spirocyclic hypervalent iodine (III)-mediated radiofluorination of nonactivated and hindered aromatics. Nat Commun. 2014;5(1): 4365-4371.

5. Rotstein BH, Wang L, Liu RY, et al. Mechanistic studies and radiofluorination of structurally diverse pharmaceuticals with spirocyclic iodonium (III) ylides. Chem Sci. 2016;7(7):4407-4417.

6. Liang CS, Wang L, Stephenson NA, Rotstein BH, Vasdev N. Facile ${ }^{18} \mathrm{~F}$ labeling of non-activated arenes via a spirocyclic iodonium (III) ylide method and its application in the synthesis of the mGluR $_{5}$ PET radiopharmaceutical $\left[{ }^{18} \mathrm{~F}\right]$ FPEB. Nat Protoc. 2019;14(5):1530-1545.

7. Deng X, Rong J, Wang L, et al. Chemistry for positron emission tomography: recent advances in ${ }^{11} \mathrm{C}-,{ }^{18} \mathrm{~F}-,{ }^{13} \mathrm{~N}$-, and ${ }^{15} \mathrm{O}$-labeling reactions. Angew Chem Int Ed. 2019;58(9):2580-2605.

8. Cardinale J, Ermert J, Humpert S, Coenen HH. Iodonium ylides for one-step, no-carrier-added radiofluorination of electron rich arenes, exemplified with $4-\left(\left(\left[{ }^{18} \mathrm{~F}\right]\right.\right.$ fluorophenoxy)phenylmethyl $)$ piperidine NET and SERT ligands. RSC Adv. 2014;4(33):1729317299.

9. Rawal VH, Cava MP. Thermolytic removal of $t$-butylcarbonyl (BOC) protecting group on indoles and pyrroles. Tetrahedron Lett. 1985;26(50):6141-6142.

10. Zinelaabidine C, Souad O, Zoubir J, Malika B, Nour-Eddine A. A simple and efficient green method for the deprotection of $N$ - 
Boc in various structurally diverse amines under watermediated catalyst-free conditions. Int J Chem. 2012;4:73-79.

11. Kuntzsch M, Lamparter D, Brüggener M, Müller M, Kienzle GJ, Reischl G. Development and successful validation of simple and fast TLC spot tests for determination of kryptofix ${ }^{\circledR} 2.2 .2$ and tetrabutylammonium in ${ }^{18} \mathrm{~F}$-labeled radiopharmaceuticals. Pharmaceuticals. 2014;7(5):621-633.

12. Vavere AL, Neumann KD, Butch ER, Hu B, DiMagno SG, Snyder SE. Improved, one-pot synthesis of 6- $\left[{ }^{18} \mathrm{~F}\right]$ fluorodopamine quality control testing for use in patients with neuroblastoma. $J$ Label Compd Radiopharm. 2018;61(14):1069-1080.

13. Jang KS, Jung YW, Sherman PS, Quesada CA, Gu G, Raffel DM. Synthesis and bioevaluation of $\left[{ }^{18} \mathrm{~F}\right] 4$-fluoro- $m$-hydroxyphenethylguanidine ( $\left.\left[{ }^{18} \mathrm{~F}\right] 4 \mathrm{~F}-\mathrm{MHPG}\right)$ : a novel radiotracer for quantitative PET studies of cardiac sympathetic innervation. Bioorg Med Chem Lett. 2013;23(6):1612-1616.
14. Jang KS, Jung YW, Gu G, et al. 4-[ $\left[{ }^{18} \mathrm{~F}\right]$ fluoro- $m$ hydroxyphenethylguanidine: a radiopharmaceutical for quantifying regional cardiac sympathetic nerve density with positron emission tomography. J Med Chem. 2013;56(18):7312-7323.

15. Murray RW, Singh M. Synthesis of epoxides using dimethyldioxirane: trans-stilbene oxide. In: Shinkai I, ed. Organic Syntheses. Vol.74 Hoboken, NJ: John Wiley \& Sons; 1997:91-100.

How to cite this article: Jung Y-W, Gu G, Raffel DM. Improved synthesis of $4-\left[{ }^{18} \mathrm{~F}\right]$ fluoro- $m$ hydroxyphenethylguanidine using an iodonium ylide precursor. $J$ Label Compd Radiopharm.

2019;62:835-842. https://doi.org/10.1002/jlcr.3791 